\title{
LISTERIAL MENINGITIS IN INFANCY
}

\author{
BY
}

\author{
J. INSLEY* and ZEENAT HUSSAIN $\dagger$ \\ From the Children's Hospital, Birmingham
}

(RECEIVED FOR PUBLICATION SEPTEMBER 5, 1963)

Listerial meningitis remains a rare disease. In the United Kingdom reports of 14 cases have appeared (Gibson, 1935; Wright and Macgregor, 1939; Edmunds, Nicholson and Douglas, 1957; Mair, Mair, Stirk and Reid, 1957; Turner, Dawson and Pryce-Jones, 1958; Barrow and Pugh, 1958; Lane, Watling and Marshall, 1959; Moore and Whitmore, 1960; Librach and Seth, 1961; McKinnon and Swithinbank, 1961; Harding and Brunton, 1962), 5 of which occurred in the newborn period. This paper describes a further 3 cases of listerial meningitis in infancy from the Birmingham Children's Hospital and remarks on the bacteriological difficulties encountered in making the diagnosis.

An analysis of 56 previously reported cases of neonatal listerial meningitis from North America and Britain is made in relation to day of onset, prematurity, fatal outcome and evidence of maternal infection. The prevalence of this disease in the neonatal period is noted and is compared with the age of onset of other forms of purulent meningitis.

\section{Case Reports}

Case 1. J.B., a girl, was born on February 3, 1954, after a normal pregnancy and delivery (birth weight $8 \mathrm{lb}$. $(3,632 \mathrm{~g})$.$) , and was the fourth child of a family of$ four. The second in this family, a boy, died of meningococcal meningitis at the age of 9 months.

For the first nine days of life she was well: on the tenth day she refused her feeds, became restless, cried unduly and at times drew up her legs. The next morning she had two generalized convulsions, each lasting about 10 minutes and characterized by eye-rolling, flickering of the eyelids and arching of the back and neck. She was admitted to hospital that same day with a provisional diagnosis of urinary infection.

She was a well-looking, active infant-weight $7 \mathrm{lb} .4$ oz. $\left(3,291\right.$ g.), her rectal temperature was $39 \cdot 2^{\circ} \mathrm{C}$., the pulse 156 and the respirations 60 per minute. There was no jaundice. The anterior fontanelle was a little full, but there was no neck stiffness and Kernig's sign

* Present address: Royal Hospital for Sick Children, Sciennes Road, Edinburgh.

+ Present address: Pathology Department, F.J. Medical College, Lahore, West Pakistan. was negative. The cry was normal. The limbs seemed unduly stiff. The spleen was just palpable, but the liver was not enlarged. The umbilicus was moist and a little inflamed.

Investigations. Haemoglobin was $120 \%$. White blood cells 29,400 per cubic mm.; $54 \%$ polymorphonuclear leucocytes; $35 \%$ lymphocytes; $11 \%$ monocytes. A turbid cerebrospinal fluid contained 7,700 white blood cells per cubis $\mathrm{mm}$. and these were mainly polymorphonuclear leucocytes. A very few Gram-positive beaded bacilli were seen, but so few that no definite diagnosis was made on the direct smear preparation. The cerebrospinal fluid sugar was $58 \mathrm{mg}$. per $100 \mathrm{ml}$.; protein $650 \mathrm{mg}$. per $100 \mathrm{ml}$. Culture under micro-aerophilic conditions yielded a scanty growth of glossy transparent colonied diphtheroids later recognized as Listeria monocytogenes. Umbilical swabs grew a few diphtheroids, which were not Listeria, and Staphylococcus aureus. There was no demonstrable abnormality in the urine and faeces. The antibiotic sensitivities of the Listeria isolated from the cerebrospinal fluid are shown in Table 1.

Treatment. Intrathecal injections of $15 \mathrm{mg}$. streptomycin, and 10,000 units crystalline penicillin, were given daily for three days. Penicillin, 250,000 units, every six hours for six days and $100 \mathrm{mg}$. streptomycin twice daily for 16 days were injected intramuscularly. Sulphadiazine, $\mathbf{0} \cdot \mathbf{3} \mathrm{g}$., every six hours, was given orally for three

TABLE 1

ANTIBIOTIC SENSITIVITIES OF THREE STRAINS DETERMINED BY DIRECT SENSITIVITY PLATES AND BY MODIFIED DITCH METHOD

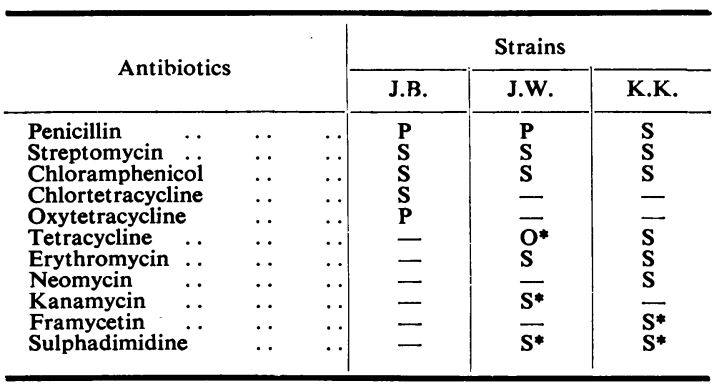

$\mathbf{P}=$ Partially sensitive; $\mathbf{S}=$ Sensitive; $\mathbf{O}=$ Insensitive.

* Sensitivities only determined on direct sensitivity plates. 
days. Sedation was with $7 \mathrm{mg}$. phenobarbitone three times a day for five days.

On this treatment the child made an uneventful recovery, the temperature falling to normal on the fourth day. She continued to feed throughout the illness and after a period of clear fluid feeding returned to a fullstrength formula of half-cream dried milk seven days after admission.

There were no sequelae to this illness. At the age of $8 \frac{1}{2}$ years she was a bright and healthy child-height $137 \mathrm{~cm}$., weight $66 \mathrm{lb}$. (29.96 kg.). A neurological examination was completely normal: head circumference $53.3 \mathrm{~cm}$.; intelligence quotient 102 (Wechsler Intelligence Scale for Children); this was considered to be a minimum figure.

Case 2. J.W. was born at home on April 21, 1961, weight $7 \mathrm{lb}$. $6 \mathrm{oz}$. (3,348 g.), after a normal pregnancy and delivery, and was the second child of a family of two. She was vigorous at birth and by the ninth day of life had regained her birth weight. On that day she became anorexic and refused part of her feeds. She then developed diarrhoea, passing frequent green watery stools which on one occasion, two days later, became streaked with blood. The second day of illness was marked by the appearance of an erythematous rash, first on the cheeks and later over the remainder of the body. On the third day she refused all feeds and was noticeably more lethargic and irritable. She was then admitted to hospital.

On admission to hospital at the age of 12 days, she appeared to be an active, well-nourished infant, weighing $6 \mathrm{lb} .14 \mathrm{oz}$. $(3,116 \mathrm{~g}$.). The rectal temperature was $37 \cdot 3^{\circ} \mathrm{C}$., the pulse 150 per minute. Her skin was pale and was covered by a fine petechial rash most noticeable over the buttocks. The respirations were irregular (60 per minute) with periods of apnoea, but the lung fields were clear to auscultation. The umbilical stump was covered with dried blood. The head circumference was $35.4 \mathrm{~cm}$. with a slightly bulging anterior fontanelle. The Moro and grasp reflexes were present and the child sucked well.

Investigations. Haemoglobin was $132 \%$. White blood cells 23,000 per c.mm.: $85 \%$ polymorphonuclear leucocytes; $11 \%$ lymphocytes; $4 \%$ monocytes. Platelets 140,000 per c.mm. A turbid cerebrospinal fluid contained 15,000 white blood cells per c.mm., these being mainly polymorphs. A moderate number of extracellular organisms were seen. These were pleomorphic slender rods and resembled Haemophilus influenzae. The cerebrospinal fluid sugar was $10 \mathrm{mg}$. per $100 \mathrm{ml}$. and the protein more than $1 \mathrm{~g}$. per $100 \mathrm{ml}$. Culture yielded a heavy growth of Listeria monocytogenes. The same organism was also isolated from a blood culture taken on the night of admission and five days later from an umbilical swab. The antibiotic sensitivities of this organism are shown in Table 1. L. monocytogenes was not isolated from either urine or faeces.

Treatment and Progress. The initial treatment was with 100,000 units of penicillin every six hours, $75 \mathrm{mg}$. chloramphenicol every six hours, $75 \mathrm{mg}$. streptomycin twice daily, and $15 \mathrm{mg}$. cortisone acetate every six hours, all by intramuscular injection. The streptomycin was continued for seven days. The penicillin and chloramphenicol were replaced after two days by kanamycin (20 mg. six-hourly intramuscularly for seven days) and erythromycin $(15 \mathrm{mg}$. six-hourly orally) once the antibiotic sensitivity of the organism became known. The erythromycin was continued for 70 days, a period that covered the reduction of cortisone dosage until its discontinuance (total course 24 days) and later a more prolonged course of prednisolone from the fourth to the tenth week of illness. There was a striking deterioration in the infant's condition within $\mathbf{1 2}$ hours of her admission: she became more irritable, developed a high-pitched cry and there was increasing opisthotonus. The skin was covered with large erythematous patches and macules as well as the purpura. That evening she had a series of fits associated with stiffness of the limbs and arching of the neck and back. Phenobarbitone, which had been given on admission (15 mg. eight-hourly), was increased to $30 \mathrm{mg}$. every six hours. Although the convulsions appeared to stop, the limbs remained unduly stiff over the next two days. The rectal temperature fell, reaching a level of $33.9^{\circ} \mathrm{C}$. some three days later. The child then appeared to improve and the sucking reflex, lost shortly after admission, returned. Three days later, nine days after the onset of treatment, the infant's condition once again deteriorated. This was characterized by loss of spontaneous movement of the arms and to a less extent of the legs. There was marked muscular hypotonia, increasing opisthotonus and loss of the sucking reflex. There was unexplained diarrhoea and vomiting. On the nineteenth day hydrocephalus was noted which was to progress (Fig. 1). Needle exploration of the subdural spaces did not yield any fluid. The cerebrospinal fluid pressure determined at the time of lumbar puncture rose normally on abdominal pressure but did not do so on jugular compression. The fluid contained $360 \mathrm{mg}$. per $100 \mathrm{ml}$. of protein compared with $70 \mathrm{mg}$. per $100 \mathrm{ml}$. in the ventricular fluid one week later. These findings were interpreted as evidence of cerebrospinal fluid block from adhesions at the base of the brain and it was to halt this progress that oral prednisolone $2.5 \mathrm{mg}$. every six hours was introduced some four weeks after the onset of illness. This dose was maintained for a further six weeks and then gradually reduced and finally discontinued. It was apparent (Fig. 1) that although this treatment had some temporary effect it failed to reverse the process that was responsible for hydrocephalus.

The first improvement noted was the reappearance of the grasp, Moro and cross extensor reflexes in the fourth week of illness. However, muscular hypotonia and opisthotonus persisted. Oral feeding was recommenced in the seventh week and tube feeding was discontinued. The infant was finally discharged from hospital at the age of $3 \frac{1}{2}$ months and at this time a development quotient was $66 \%$ (Ruth Griffiths scale). After leaving hospital the hydrocephalus progressed, and at the age of $6 \frac{1}{2}$ months an external rectus palsy of the right eye appeared. At the age of 18 months she had good head control. 


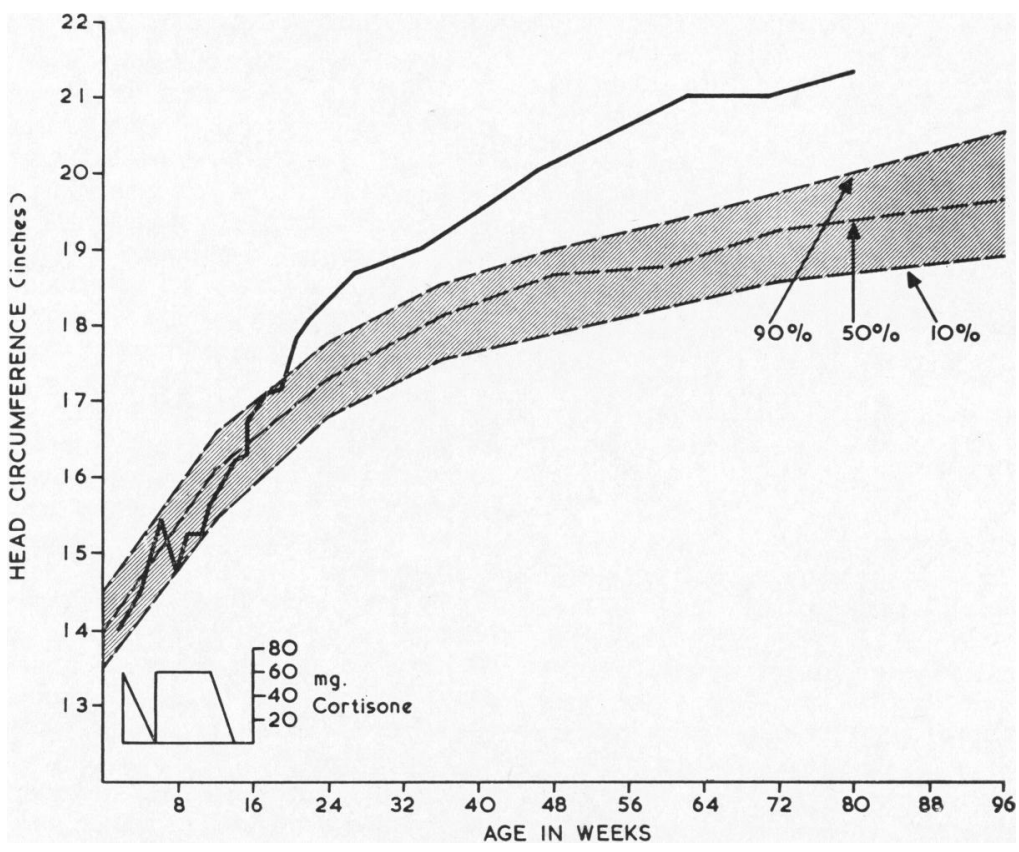

FIG. 1.-Comparison between the progressive increase in the head circumference of Case 2 with that of normal skull growth (shaded area). The prednisolone dosage is expressed as cortisone ( $1 \mathrm{mg}$. prednisolone $=5 \mathrm{mg}$. cortisone).

The head circumference was $51 \mathrm{~cm}$. She sat without support. There was evidence of a mild right-sided spastic hemiplegia. A development quotient was then $75 \%$. At 23 months of age, after a day's illness, she had a generalized convulsion. The cerebrospinal fluid obtained at lumbar puncture did not contain any cells. The cerebrospinal fluid protein was $45 \mathrm{mg}$. per $100 \mathrm{ml}$; cerebrospinal fluid sugar $97 \mathrm{mg}$. per $100 \mathrm{ml}$. She was treated with phenobarbitone, $15 \mathrm{mg}$. b.d. She walked with aid at the age of 2 years.

Case 3. K.K., a girl, was the tenth surviving member of a family of 12 Indian children. The two eldest children had died in India and the remaining 10 had been born in this country. She was born in hospital on August 14, 1962, birth weight $5 \mathrm{lb} .7 \mathrm{oz}$. $(2,466 \mathrm{~g}$.), after a normal delivery and an apparently normal pregnancy. Mother and child were discharged home on the sixth day after an uneventful puerperium. At the age of 3 months, on November 17, she refused her feeds and later vomited. Subsequently she passed two to three yellowish-green watery motions per day; she became irritable and cried continuously.

On the third day of illness when she was admitted to hospital she was an ill child with a high-pitched cry. Her weight was $7 \mathrm{lb} .7 \mathrm{oz}$. $(3,374 \mathrm{~g}$.), the rectal temperature was $38.3^{\circ} \mathrm{C}$., the pulse was 150 per minute and the respirations 58 per minute. The fontanelle was tense and the head circumference was $35 \mathrm{~cm}$. The left ear drum was inflamed. The limbs were unduly stiff. Kernig's test was positive.

Investigations. Haemoglobin was $62 \%$. White blood cells 7,000: $54 \%$ polymorphonuclear leucocytes; $4 \%$ lymphocytes; $4 \%$ monocytes. Lumbar puncture yielded a slightly turbid fluid containing 1,300 white blood cells per c.mm. and these were mainly polymorphonuclear leucocytes. A few Gram-positive rods were seen. The cerebrospinal fluid sugar was $12 \mathrm{mg}$. per $100 \mathrm{ml}$; protein $300 \mathrm{mg}$. per $100 \mathrm{ml}$. Culture yielded a heavy growth of $L$. monocytogenes. The antibiotic sensitivities of this organism are shown in Table 1. The urine contained $80 \mathrm{mg}$. of protein and numerous granular casts, but was sterile on culture. L. monocytogenes was not isolated from the throat swab or the faeces.

Progress and Treatment. Treatment was commenced on admission with $150 \mathrm{mg}$. chloramphenicol every six hours; $100 \mathrm{mg}$. b.d. streptomycin and $125 \mathrm{mg}$. sulphadimidine every six hours-all intramuscularly. The streptomycin was continued for a period of 12 days, but after three days the other two drugs were given orally (40 mg. chloramphenicol every six hours for eight days, and $250 \mathrm{mg}$. sulphadimidine every six hours for 10 days). In view of the infant's critical condition prednisone was also started at the time of admission, $2.5 \mathrm{mg}$. every eight hours. This dose was reduced on the third day and the drug finally discontinued nine days after admission. Sedation was with $15 \mathrm{mg}$. phenobarbitone every six hours, first intramuscularly, and then, after three days, orally. This was reduced on the fourth day to $15 \mathrm{mg}$. twice daily and discontinued two weeks later. Initially the infant received intravenous fluids, but after two days was able to tolerate gastric tube feeds. After five days' treatment the infant was again able to suck and thereafter took from the bottle. Subsequent 
TABLE 2

THE C.S.F. DEPOSIT FROM THREE CASES: RESULTS OF GRAM STAIN, CULTURE AND EXAMINATION FOR MOTILITY

\begin{tabular}{|c|c|c|c|c|c|}
\hline \multirow[t]{2}{*}{ Case } & \multirow[t]{2}{*}{ Gram Stain } & \multicolumn{2}{|c|}{$\begin{array}{c}\text { Colonial Morphology } \\
\text { (18-hour culture at } 37^{\circ} \mathrm{C} . \\
\text { under micro-aerophilic conditions) }\end{array}$} & \multicolumn{2}{|c|}{$\begin{array}{l}\text { Motility in } 0 \cdot 15 \% \text { Glucose } \\
\text { Infusion Broth } \\
\text { (18-hour culture at } 37^{\circ} \mathrm{C} \text {.) }\end{array}$} \\
\hline & & Blood Agar & Chocolate Agar & $37^{\circ} \mathrm{C}$. & $25^{\circ} \mathrm{C}$. \\
\hline 1 & $\begin{array}{l}\text { Many polymorphs; } \\
\text { very few Gram- } \\
\text { positive rods of } \\
\text { beaded appearance }\end{array}$ & 1 mm. in diameter; & $\begin{array}{l}\text { Smaller than on blood } \\
\text { a g a r; s h in ing, }\end{array}$ & $\underset{\text { present }}{\text { Tumbling motility }}$ & Not done \\
\hline 2 & $\begin{array}{l}\text { Numerous W.B.C., } \\
\text { mainly polymorphs; } \\
\text { many extracellular } \\
\text { pleomorphic rods } \\
\text { easily decolorized to } \\
\text { resemble } H . \text { influ- } \\
\text { enzae }\end{array}$ & $\begin{array}{l}\text { surrounded by a } \\
\text { narrow zone of } \\
\text { beta haemolysis }\end{array}$ & $\begin{array}{l}\text { no discoloration of } \\
\text { surrounding medium }\end{array}$ & ", & $\underset{\text { present }}{\text { Tumbling motility }}$ \\
\hline 3 & $\begin{array}{l}\text { Numerous W.B.C., } \\
\text { mainly polymorphs; } \\
\text { a moderate number } \\
\text { of short bea ded } \\
\text { Gram-positive rods } \\
\text { easily decolorized }\end{array}$ & & & $\begin{array}{l}\text { Motility absent in } \\
\text { primary culture, but } \\
\text { appeared after in- } \\
\text { oculation and incu- } \\
\text { bation of further } \\
\text { tube of } 0 \cdot 15 \% \text { glu- } \\
\text { cose at } 37^{\circ} \text { C. for } \\
8 \text { hours }\end{array}$ & ," \\
\hline
\end{tabular}

progress was uneventful. At the time of discharge three weeks after admission she was well, weight $9 \mathrm{lb} .3 \mathrm{oz}$. $(4,170 \mathrm{~g}$.). She smiled, seemed interested and responded to noise. The head circumference was $37 \cdot 5 \mathrm{~cm}$. Muscular tone was normal. The neonatal reflexes could not be elicited.

\section{Bacteriological Investigations}

L. monocytogenes was isolated from the cerebrospinal fluid of all three cases and from a blood culture taken from Case 2 at the time of admission. It was also isolated from the umbilicus of this infant after she had been treated for five days.

The results of the Gram stain and the culture of the cerebrospinal fluid deposit as well as the presence of or absence of characteristic tumbling motility are recorded in Table 2 .

The techniques used for the culture of the cerebrospinal fluid deposit were those normally employed in the Birmingham Children's Hospital and were as follows.

The deposit was cultured by seeding it on to blood agar and chocolate agar and also by inoculating a $0.15 \%$ glucose infusion broth. When the organism appeared to be Gram-negative McConkey's litmus medium was likewise inoculated. Antibiotic sensitivities were determined at this stage on direct sensitivity plates. The blood agar, chocolate agar and sensitivity plates were then incubated micro-aerophilically at $37^{\circ} \mathrm{C}$. for 18-24 hours as described by Rogers, Zinnemann and Foster (1960). Sterile cultures were then reincubated for a further 24-48 hours.

Antibiotic Sensitivities. The antibiotic sensitivities of the three strains were either determined by a modified ditch method or on direct sensitivity plates as shown in Table 1. The strain from J.W. was resistant to tetracycline but appeared highly sensitive to kanamycin.
In view of the unexpected results and the critical condition of the infant the sensitivities of this strain to various antibiotics were redetermined by the serial dilution method of Fleming (1942): the results are shown in Table 3, these quantitative estimations confirming the original qualitative findings.

Biochemical Reactions. These results were in keeping with those normally obtained for L. monocytogenes.

Animal Pathogenicity. Animal pathogenicity was determined after the intravenous injection of rabbits with the strains from J.B. and J.W. and by the intraperitoneal inoculation of a guinea-pig with strain K.K. At autopsy the classical multiple liver abscesses were noted, Listeria being isolated from each animal.

The Production of Monocytosis. $1 \mathrm{ml}$. $\left(5 \times 10^{8}\right.$ organisms) of a broth culture of strain J.B. was inoculated intravenously into a rabbit. The organism was recovered from a blood culture taken 48 hours later. The rabbit became anorexic and lethargic on the second and third day, while the blood count showed a monocytosis on

TABLE 3

IN VITRO ANTIBIOTIC CONCENTRATIONS REQUIRED TO PRODUCE BACTERIOSTASIS OF STRAIN J.W., COMPARED WITH THOSE OF OXFORD STAPHYLOCOCCUS

\begin{tabular}{|c|c|c|c|}
\hline Antibiotic & & $\begin{array}{c}\text { C.S.F. Strain } \\
\text { (J.W.) }\end{array}$ & $\begin{array}{c}\text { Oxford } \\
\text { Staphylococcus }\end{array}$ \\
\hline $\begin{array}{l}\text { Penicillin (Oxford units } / \mathrm{ml} .) \\
\text { Oxytetracycline }(\mu \mathrm{g} . / \mathrm{ml} .) \\
\text { Erythromycin }(\mu \mathrm{g} . / \mathrm{ml} .) \\
\text { Streptomycin }(\mu \mathrm{g} . / \mathrm{ml} .) \\
\text { Methicillin }(\mu \mathrm{g} . / \mathrm{ml} .) \quad \ldots \\
\text { Kanamycin }(\mu \mathrm{g} . / \mathrm{ml} .) \quad \ldots\end{array}$ & $\begin{array}{l}\cdots \\
\cdots \\
\cdots \\
\cdots \\
\cdots\end{array}$ & $\begin{array}{l}0 \cdot 6 \\
94 \\
0 \cdot 75 \\
5 \cdot 9 \\
5 \cdot 5 \\
0 \cdot 38\end{array}$ & $\begin{array}{l}0 \cdot 075 \\
0 \cdot 15 \\
0 \cdot 75 \\
5 \cdot 9 \\
1 \cdot 1 \\
1 \cdot 25\end{array}$ \\
\hline
\end{tabular}




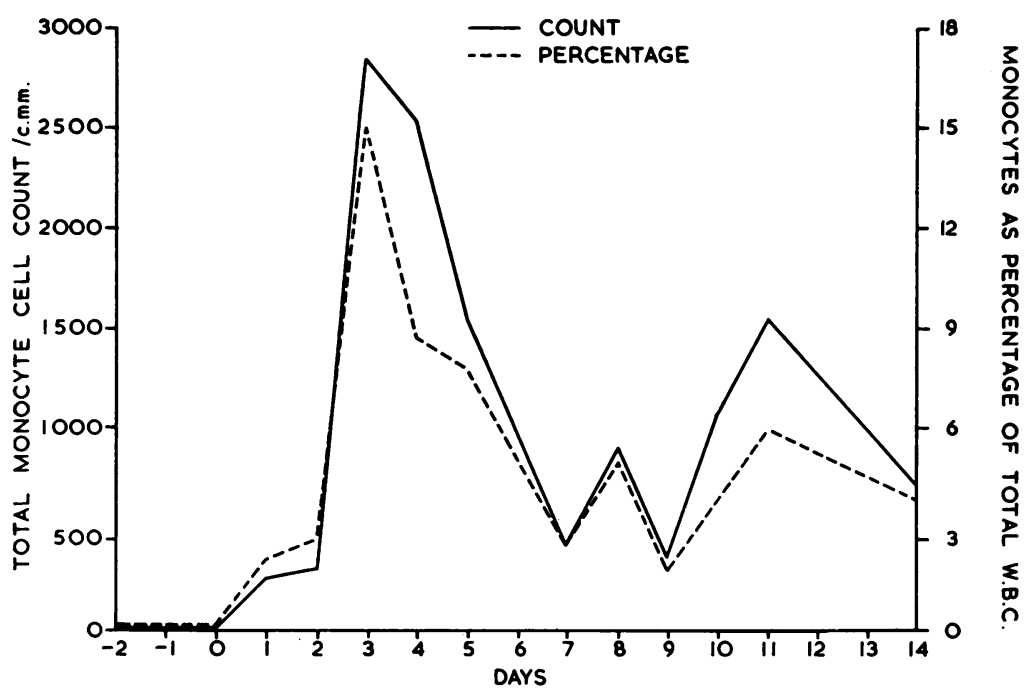

Fig. 2.-The monocytic response produced in a rabbit after an intravenous injection of a broth culture of the organisms from Case 1.

the fourth (Fig. 2). There was a rise of ' $O$ ' antibody titre from $1 / 250$ on the seventh day to $1 / 1,250$ on the fourteenth day. The ' $H$ ' antibody titre was $1 / 250$ on the seventh day and rose no higher. When the animal was killed on the fourteenth day miliary nodules were found in the liver.

Conjunctival Test. Two drops of 18 -hour broth cultures prepared from the strains J.B. and K.K. were instilled into the conjunctival sacs of rabbits. Conjunctivitis was not produced.

Serology. Antibodies were not detected in the serum of J.B. and K.K. These findings were confirmed by Dr. H. P. R. Seeliger of Bonn University.

Serological Typing. The three strains were serotyped by Dr. Seeliger. Strains J.B. and J.W. were serotype 4b and strain K.K. serotype 1.

\section{Epidemiology}

The vaginal swabs and all those swabs taken in the various parts of the house in which K.K. lived were treated as pus (Rogers and Heslop, 1948). They were initially seeded on to composite blood agar, McConkey's litmus agar and Hoyle's potassium tellurite medium and inoculated into a tube of glucose infusion broth. Throat swabs were inoculated on the above-mentioned media as well as on to a chocolate agar medium.

The composite blood agar and chocolate agar were incubated micro-aerophilically at $37^{\circ} \mathrm{C}$., while Hoyle's potassium tellurite medium, McConkey's litmus agar and the $0.15 \%$ glucose infusion broth were incubated aerobically at the same temperature. These media were examined daily for the next two weeks for the presence of colonies resembling Listeria.

After the initial inoculation all the specimens related to Case 3 were refrigerated at $4^{\circ} \mathrm{C}$. for six weeks, and at weekly intervals each specimen was inoculated on to two blood agar plates. One of these plates was incubated micro-aerophilically at $37^{\circ} \mathrm{C}$., while the second was incubated aerobically at $4^{\circ} \mathrm{C}$. The media were examined daily for two weeks for the presence of colonies resembling Listeria.

Case 1. Listeria was not isolated from the throat or nasal swabs taken from the parents on the fourth and twelfth days of the baby's illness. Faeces obtained from them were similarly negative. No agglutinating antibodies were detected in the blood of either parent, taken during the seventh week of illness.

Case 2. Listeria was not isolated from the mother's high and low vaginal swabs obtained on the second day of the infant's illness.

Case 3. High and low vaginal swabs were obtained from the mother. There were five adults and, in addition to Case 3 (K.K.), nine children, as well as a cat and a dog, living in a nine-roomed house. Throat swabs and faeces were obtained from all these, including the cat and dog, while further specimens were collected by swabbing fomites and various parts of the house with swabs moistened with $0.15 \%$ glucose infusion broth. Listeria was not recovered from any of these specimens. Throat swabs from the dog and three of the younger siblings yielded a Gram-positive motile rod that showed beta haemolysis after three to four days incubation. Dr. Seeliger examined this organism and found that it was not $L$. monocytogenes.

She walked unaided when she was 14 months old, and at that time she said one word with meaning. Her hearing was thought to be normal. She weighed $16 \mathrm{lb}$. $3 \mathrm{oz}$. $(7 \cdot 38 \mathrm{~kg}$.), and her length was $70 \mathrm{~cm}$. 


\section{Discussion}

The strains of $L$. monocytogenes isolated from these three cases of meningitis conformed to the accepted bacteriological and biochemical criteria for this organism (Murray, 1955; Seeliger, 1961a).

The Gram stain smears of the fresh cerebrospinal fluid deposits of Cases 2 and 3 were difficult to interpret. Several smears of each were examined; the staining of the smear from Case 2 was not consistent, many of the bacilli appearing Gramnegative, but in Case 3 the organisms were shown to be Gram-positive more easily. In Case 2 we mistook this organism for $\boldsymbol{H}$. influenzae as had others (Moore and Whitmore, 1960; Easton, Fallon and French, 1962). Seeliger (1961b) noted that this was due to the ease with which this organism in the fresh cerebrospinal fluid deposit became decolorized by acetone after Gram staining.

We failed to produce conjunctivitis after inoculation of the conjunctival sacs of rabbits with 18-hour broth cultures of the two strains (strains of J.W. and K.K.) in which it was attempted. The use of an ageing culture in the first experiment may have been one factor that led to this negative result.

The in vitro antibiotic sensitivities of our three strains are shown in Table 2. The resistance of strain J.W. to tetracycline was an unexpected feature, since Seeliger (1961c) considered tetracycline to be the drug of choice in the treatment of this disease. Because the child was so obviously getting worse, treatment was changed to those bactericidal drugs that were thought to have most chance of passing the blood-brain barrier, the infection being finally eradicated by this combination of erythromycin, kanamycin and streptomycin. The other two infants who were less severely ill made a good response to treatment, one with penicillin, streptomycin and sulphadiazine, the other to a combination of chloramphenicol, streptomycin and sulphadimidine.

The epidemiology was not fully investigated in Cases 1 and 2. A high vaginal swab was not obtained from the mother of Case 1 and some five weeks elapsed before the serology of either parent could be carried out. No antibodies were detected in the blood of Case 2. Although high and low vaginal swabs from the mother were cultured at the time of the child's admission, these were not incubated at $4^{\circ} \mathrm{C}$. or re-examined after refrigeration. In Case 3 we were unable to recover the organism from the vaginal swab taken from the mother 10 days after the child's admission to hospital. The throat swabs and specimens of faeces obtained from other members and the animals living in that house did not yield Listeria. Serological testing was only carried out in the infant and her mother. The blood of Case 3, like that of Case 1, did not contain any antibodies to L. monocytogenes. This was not an unexpected finding since Murray (1955) and Seeliger (1961d) had both noted that these antibodies were absent in the blood of infants under 6 months of age. The mother's blood on the other hand showed a titre of 1/320 against an ' $O$ ' antigen and of $1 / 20$ against an ' $H$ ' antigen, two weeks after the onset of the illness of the child: these titres fell to $1 / 80$ against the ' $O$ ' and became undetectable against the ' $\mathrm{H}$ ' antigen some two and a half weeks later. H. P. R. Seeliger (1962, personal communication) considered this indicative of maternal infection.

The incidence of human listeriosis is highest in the first month of life (Nichols and Woolley, 1962), only a few cases occurring thereafter until old age is reached. Reports appearing in North America and Britain together cite 56 cases of listerial meningitis recognized in the first month of life (Finegold, Bradley, Campbell and Greenberg, 1954; Johnston, Morton, Wong and Roy, 1955; Edmunds et al., 1957; Barrow and Pugh, 1958; Moore and Whitmore, 1960; Harding and Brunton, 1962; Nichols and Woolley, 1962) while only 10 further cases are noted in the ensuing 11 months (Finegold et al., 1954; Edmunds et al., 1957; Turner et al., 1958; Nichols and Woolley, 1962). This propensity for the neonatal period is similar to that of Esch. coli and other forms of meningitis due to Gram-negative bacilli and is at variance with the incidence of other forms of meningitis usually met with in childhood. This difference is brought out in Figs. 3 and 4 which show the age of onset and bacterial type of 116 consecutively reported cases of acute purulent meningitis at the Birmingham Children's Hospital during the five-year period 1958 to 1963 . In this series only four cases of neonatal meningitis were noted in otherwise normal infants. In two the offending organism was Esch. coli, in one Ps. pyocyaneus, and in one L. monocytogenes. Fig. 5 represents those 56 cases of listerial meningitis previously recorded in the first month of life and also two of our own plotted against the day of onset of illness and so roughly divides them into two groups. The 10 infants in group ' $A$ ' were either ill at birth or showed signs of illness on the first day of life, the remaining 48 (group ' $B$ ') were well at birth but became ill sometime between the fourth and 28th days. Those in group ' $A$ ' were commonly described as being prematurely born, were of low birth weight (mean birth weight of nine cases $4 \mathrm{lb} .15 \mathrm{oz}$. $(2,250 \mathrm{~g})$.$) and rapidly succumbed.$ $L$. monocytogenes was isolated from the vaginal swabs of three of the mothers (Luttor, 1958; 


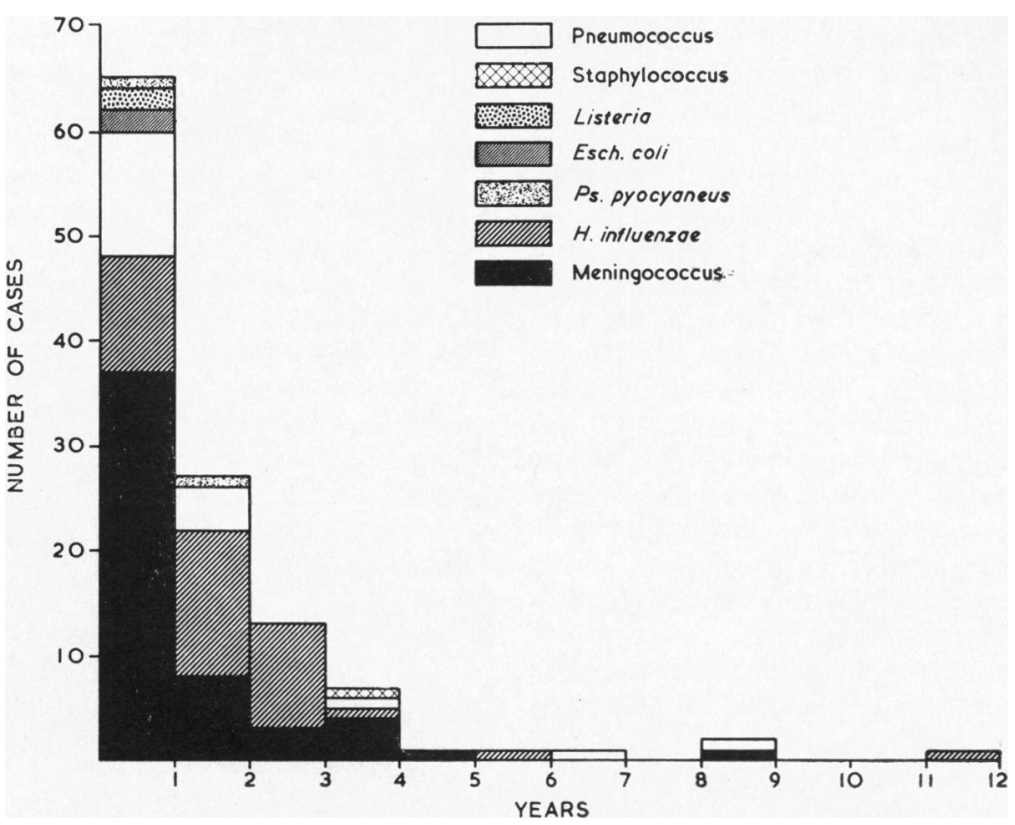

Fig. 3.-The causative organisms cultured from 116 cases of purulent meningitis seen in the Birmingham Children's Hospital during the five-year period 1958-63 and relation to age of onset.

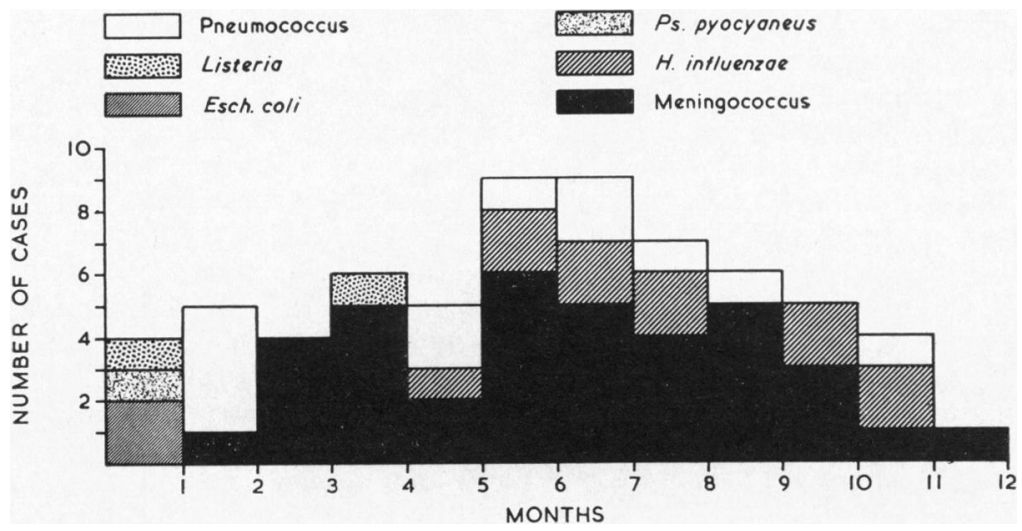

FIG. 4.-65 cases of bacterial meningitis noted in the first year of life in Fig. 3 further divided according to month of age of onset.

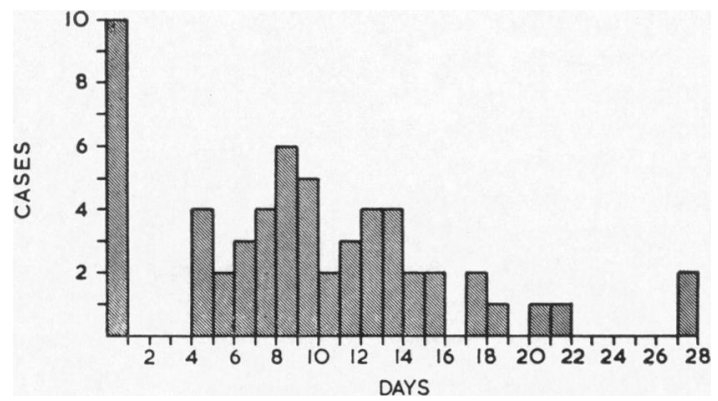

Fig. 5.-The day of onset of 58 cases of $L$. monocytogenes meningitis presenting during the first month of life. 
Johnston et al., 1955) and in a fourth there was a suggestive history of maternal illness preceding the birth (Burn, 1936). The majority of infants in group 'B' were on the other hand born at term after normal pregnancies and many were of normal birth weight (mean birth weight of 31 cases was $6 \mathrm{lb}$. $10 \mathrm{oz}$. $(3,022$ g.)). They remained well and thrived until the onset of symptoms. Although the whole series did not receive antibiotic treatment, 23 out of a total of $41(56 \%)$ survived the immediate illness. Maternal infection was less commonly demonstrated, being only confirmed in one case (Hood, 1961) and suspected in another (Burn, 1936). There is little doubt that the infants in group ' $A$ ' were infected before birth and this precipitated delivery. Experimental evidence (Gray, Singh and Thorp, 1955) also suggests that those in group ' $B$ ' became infected shortly before or at the time of delivery.

Apart from transplacental infection and rare cases of listerial cross-infection in newborn nurseries (Line and Cherry, 1952; Levy and Nassau, 1960), human-to-human transmission of this disease has yet to be recognized. With this in mind two alternative explanations were put forward to explain the late onset of illness and the evidence of maternal infection in Case 3. Either mother and child suffered quite independent illnesses, each having been infected from the same source, or the infant was infected at, or harboured the organism from, birth and yet did not show signs of infection until the age of 3 months. Ekelund, Laurell, Melander, Olding and Vahlquist (1962) state that L. monocytogenes could be found in the meconium of otherwise normal newborn infants and Neils Dungal's (1961) description of four sibs with subacute infection following intrauterine infection supports the second of these possibilities. H. P. R. Seeliger (personal communication) himself felt that there was increasing evidence that listeriosis of the newborn might only become manifest after considerable delay following infection.

\section{Summary}

Three previously unreported cases of listerial meningitis are described. Symptoms appeared during the second week of life in two and at the age of 3 months in the third. An earlier history of maternal illness could not be elicited and bacteriological evidence of maternal infection was not found, but in the mother of the 3-month-old infant there was serological evidence of past infection from Listeria. It is suggested that this infant became infected at, or shortly before, birth and subsequently harboured the organism for three months before showing evidence of clinical infection.
All three infants survived, two apparently well, the other with severe neurological sequelae.

The Gram stain of the cerebrospinal fluid deposit was difficult to interpret in two of the cases since the organism decolorized easily and the characteristic tumbling motility was apparently absent in one strain possibly following a change in the $p \mathrm{H}$ of the liquid medium in which it had been cultured.

Fifty-eight cases of listerial meningitis reported during the neonatal period were analysed regarding the day of onset of the illness. They fell into two groups; those in Group A were ill on the first day of life, while the others (Group B) developed clinical manifestations between the fourth and 28th days. The infants in Group A were thought to have been infected in utero; those in Group B at, or shortly before, birth.

Among 116 cases of purulent meningitis diagnosed during the five-year period 1958-1963 in the Birmingham Children's Hospital, only four occurred during the first month of life in otherwise normal infants. Of these, two were due to Esch. coli, one to Ps. pyocyanea and one to L. monocytogenes.

We would like to thank Dr. W. H. P. Cant, Dr. W. C. Smallwood and Dr. B. S. B. Wood who allowed us to publish these cases, and the other physicians of the Birmingham Children's Hospital who gave us access to their files. We are indebted to Dr. H. P. R. Seeliger of Bonn for his advice, for serotyping our three strains and the many serological investigations he undertook on our behalf, and to Dr. K. B. Rogers who identified all three strains and carried out all the original bacteriological investigations in Case 1 and for his advice in the subsequent studies and construction of this article. The Development Quotients were kindly determined by Dr. B. S. B. Wood and the Intelligence Quotient by Miss J. E. Reiner, educational psychologist to the City of Birmingham Education Committee. We are extremely grateful for the secretarial help given by Miss E. Dawson.

REFERENCES

Barrow, G. I. and Pugh, R. J. (1958). Listeria (erysipelothrix) monocytogenes meningitis in the newborn. J. Path. Bact., $75,9$.

Burn, C. G. (1936). Clinical and pathological features of an infection caused by a new pathogen of the genus Listerella. Amer. J. Path., 12, 341 .

Dungal, N: (1961). Listeriosis in four siblings. Lancet, 2, 513.

Easton, H. G., Fallon, R. J. and French, V. (1962). Listeria monocytogenes meningitis in neonates. ibid., 2, 665 .

Edmunds, P. N., Nicholson, D. N. and Douglas, D. M. (1957). Two cases of Listeria meningitis in infants. Brit. med. J., $2,188$.

Ekelund, H., Laurell, G., Melander, S., Olding, L. and Vahlquist, B. (1962). Listeria infection in the foetus and the new-born. A clinical, pathological and epidemiological study. Acta paediat. (Stockh.), 51, 698.

Finegold, S. M., Bradley, J. G., Campbell, M. K. and Greenberg, A. J. (1954). Listeria monocytogenes meningitis. Summation of literature and report of two new cases. Arch. intern. Med., 93, 515.

Fleming, A. (1942). In-vitro tests of penicillin potency. Lancet, $1,732$.

Gibson, H. J. (1935). A pathogenic diphtheroid bacillus from a fatal case of meningitis. J. Path. Bact., 41, 239. 
Gray, M. L., Singh, C. and Thorp, F. (1955). Abortion, stillbirth, and early death in rabbits by Listeria monocytogenes. II. Oral exposure. Proc. Soc. exp. Biol. (N.Y.), 89, 169.

Harding, J. W. and Brunton, G. B. (1962). Listeria monocytogenes meningitis in neonates. Lancet, $2,484$.

Hood, M. (1961). Listeriosis as an infection of pregnancy manifested in the newborn. Pediatrics, 27, 390.

Johnston, W. H., Morton, S. A., Wong, M. H. and Roy, T. E. (1955) Septicaemia of the newborn due to Listeria monocytogenes. Canad. med. Ass. J., 73, 402.

Lane, W. F., Watling, J. and Marshall, J. (1959). A case of meningitis caused by Listeria monocytogenes. Mth. Bull. Minist. Hlth Lab. Serv., 18, 127.

Levy, E. and Nassau, E. (1960). Experience with Listeriosis in the newborn. An account of a small epidemic in a nursery ward. Ann. Paediat. (Basel), 194, 321.

Librach, I. M. and Seth, R. K. (1961). Human Listerial meningitis. J. clin. Path., 14, 193.

Line, F. G. and Cherry, W. B. (1952). Meningitis due to Listeria monocytogenes: Report of two cases. J. Amer. med. Ass., 148, 366.

Luttor, C. (1958). A case of neonatal death due to listeriosis and a review of the problem. Amer. J. Obstet. Gynec., 75, 759.

Mair, H. J., Mair, N. S., Stirk, E. M. and Reid, A. W. (1957). Two cases of meningitis due to Erysipelothrix monocytogenes. J. clin. Path., 10, 231.
McKinnon, D. and Swithinbank, J. M. (1961). Meningitis due to Listeria monocytogenes. Lancet, 2, 516.

Moore, S. and Whitmore, D. N. (1960). Case of Listeria meningitis Brit. med. J., 2, 1572.

Murray, E. G. D. (1955). A characterization of Listeriosis in man and other animals. Canad. med. Ass. J., 72, 99.

Nichols, W. and Woolley, P. V. (1962). Listeria monocytogenes meningitis. Observations based on 13 case reports and a consideration of recent literature. J. Pediat., 61, 337.

Rogers, K. B. and Heslop, W. (1948). The use of the selective inhibitory action of toluene on coliform bacilli in routine cultures. J. clin. Path., 1, 315.

- Zinnemann, K. and Foster, W. P. (1960). The isolation and identification of Haemophilus SPP. from unusual lesions in children. J. clin. Path., 13, 519.

Seeliger, H. P. R. (1961a). Listeriosis, p. 205. Karger, Basel and New York.

— (1961b). ibid., p. 207.

(1961c). ibid., p. 190.

(1961d). ibid., p. 236.

Turner, G. C., Dawson, I. M. P. and Pryce-Jones, E. (1958). Fatal Listeria monocytogenes meningitis in a child aged 3 months. J. clin. Path., 11, 266.

Wright, H. A. and Macgregor, A. R. (1939). A case of meningitis due to Bacterium monocytogenes. J. Path. Bact., 48, 470. 